\section{Preliminary screening, isolation and identification of microbial phytase producers from soil}

\author{
Akshita Nagar, Asmita Kamble, Harinder Singh* \\ Department of Biological Sciences, Sunandan Divatia School of Science, NMIMS Deemed to be \\ University, Mumbai 400056, India \\ ${ }^{\star}$ Corresponding author, E-mail: Harinder.Singh@nmims.edu
}

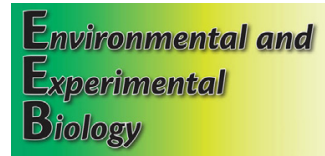

ISSN 2255-9582

UNIVERSITY OF LATVIA

\begin{abstract}
Phytate is a widely found form of phosphate in plant seeds that can be hydrolysed by phytase enzyme to release phosphate and myoinositol intermediates. Phytase has been mainly used in feed and aquaculture to reduce the anti-nutritional effect and eutrophication caused by phytate. The present study focused on preliminary screening, isolation and characterization of phytase producers from soil. A total of eleven soil samples were collected and screened by plate assay on phytase screening media followed by isolation of phytase producers to obtain pure cultures. Biochemical assays, $16 \mathrm{~s}$ rDNA restriction fragment length polymorphism and 16s rDNA sequencing were performed for identification of phytase producers. The intracellular and extracellular phytase activity was measured by a modified Heinonen method at $\mathrm{pH}$ 2.5, 5.0 and 7.5. The activity of bacterial phytase producers (PSD5TSB, CD5, VD5 FD5O, FD2 and FD5T) was compared with the wild type Escherichia coli phytase. The optimum $\mathrm{pH}$ for enzyme activity from the soil isolates was observed at $\mathrm{pH}$ 5. From soil samples from eleven different sources, presence of bacterial phytase producers was confirmed in four soil samples by this preliminary screening method. The simple plate screening and activity assay helped in isolating phytase producers from soil, which can be used as potential candidates for phytase production.
\end{abstract}

Key words: phytase, phytase activity, phytase producers, soil.

Abbreviations: LB, Luria-Bertani; PSA, phytase screening agar; PSB, phytase screening broth; RFLP, restriction fragment length polymorphism; TS, tryptic soy.

\section{Introduction}

Phytic acid is a type of organic phosphorous with the chemical name myo-inositol hexakisdihydrogen phosphate (Dahiya 2016). It is found in seeds of crops such as wheat, barley, soybean, rice, maize, groundnut, legumes, and nuts. It is primary source of inositol and the storage form of phosphorous as well as minerals in plant seeds (Mittal et al. 2011; Kim et al. 2015; Baruah et al. 2017). Phosphorous is an essential macronutrient, utilized in plant metabolism processes such as photosynthesis, respiration and cell division (Karpagam, Nagalakshmi 2014; Motamedi 2016).

Cereals and oilseeds are used as feed for monogastric animals like chicken, pigs and fish, in which phytate has an anti-nutritional effect (Baruah et al. 2017). This is due to the lack of phytase producing intestinal microbiota, which leads to excretion of non-utilized phosphorous, causing environmental pollution (Bohn et al. 2008). On the other hand, phytate has the ability to chelate mineral cations that reduces their solubility (Baruah et al. 2017). Phytate can also form complexes with amino acids and proteins, lipids, starch and vitamins, resulting in reduced absorption of these nutrients (Costenaro-Ferreira, Della Flora 2017;
Savita et al. 2017). However, moderate consumption of phytate can be beneficial. For instance, it has been shown to have antioxidant and anticancer effect, prevent renal lithiasis, lower the glycaemic index and balance glucose and cholesterol levels (Grases, Costa-Bauza 2019).

Myo-inositol hexakisphosphate hydrolase, also known as phytase, is a phosphatase enzyme found in animals, plants and microorganisms (Savita et al. 2017). Phytase cleaves phytic acid or its salt derivatives by hydrolysis to produce free inorganic phosphorous and inositol intermediates with lesser phosphate (Dvořáková 1998). Phytase first hydrolyses all of the hexaphosphate to penta-esters and then moves forward for further dephosphorylation to tetra-esters and so on (Dersjant-Li et al. 2015). The action of the enzyme decreases the affinity of substrate to cations and provides a free source of phosphorous (Bohn et al. 2008).

There are broadly two classes of phytase, first depending on the position of dephosphorylation on the inositol ring and second based on the catalytic mechanism (Dvořáková 1998; Mullaney, Ullah 2003; Greiner et al. 2007; Nasrabadi et al. 2018). The first class includes 3-phytase (EC 3.1.3.8), a class produced by microorganisms; 4/6-phytase (EC 3.1.3.26), mainly produced by plants; and 5-phytase (EC 
3.1.3.72), found in several legumes such as Pisum sativum, Phaseolus vulgaris and Medicago sativa (Greiner, Carlsson 2006; Bhavsar, Khire 2014). In the second class, there are acidic (EC 3.1.3.2) and alkaline (EC 3.1.3.8) phytase enzymes. Phy A-3-phytase, Phy B-3-phytase, Phy C-6phytase belong to a subclass of histidine acid phosphatase. Histidine acid phosphatase, cysteine acid phosphatase and purple acid phosphatase are types of acidic phytase (Bhavsar, Khire 2014). Alkaline phytase includes $\beta$-propeller phytase, which has a subtype, Phy D-3 phytase, produced by Bacillus sp. (Mullaney, Ullah 2003; Bhavsar, Khire 2014).

Microbial phytases have been studied due to their diverse action, economic advantage at different scale, high activity and high production turn-around time (Ushasree et al. 2017). Phytase is known to promote mineral absorption and increase their bioavailability, reduce nonutilized phytate, decrease mineral deficiency and improve bone health in animals (Dahiya 2016). Until now, phytase has been used commercially as poultry, swine and fish feed, thus saving the use of irreplaceable and expensive inorganic phosphate as well as preventing fungal blooms that leads to eutrophication (Lei, Porres 2003; Bajaj, Wani 2015; Nasrabadi et al. 2018). Microbial phytase is used as an innovative approach in the livestock industry as feed, and in the farming industry as fertilizer, as well as for environmental protection (Akhmetova et al. 2013; Suleimanova et al. 2015). Other applications where phytase is of great interest are the food industry, healthcare and medicine, and aquaculture (Kumar et al. 2010; Shobirin et al. 2010; Caipang et al. 2011; Rocky-Salimi et al. 2016).

An ideal phytase should have high specific activity for phytate substrate, be functionally stable at a wide range of $\mathrm{pH}$ and temperature, be resistant towards proteases, be thermostable, and retain stability during harsh processing conditions, during storage of feed as well as in the gut (Lei, Porres 2003; Savita et al. 2017). Methods to improve thermostability of phytase were described (Coutinho et al. 2020). These included identifying novel resistant microbial sources, engineering recombinant phytase from genetically modified microorganisms, substituting amino acids in the enzyme molecule and immobilizing the unstable and thermosensitive phytase to insoluble supports.

Several phytase-producing bacteria have been discovered and studied, such as Bacillus sp., Pseudomonas sp. and Raoultella sp., Escherichia coli (Konietzny, Greiner 2004). E. coli AppA phytase has optimum activity at acidic $\mathrm{pH}$ and shows specific activity towards phytate, deeming it to be a good source of phytase for industrial application (Golovan et al. 1999). Many studies have been conducted to discover novel phytase producing bacteria that could satisfy the industrial needs, but have not been up to the mark (Goodfellow, Fiedler 2010; Nasrabadi et al. 2018), which has led to recombinant engineering of many phytase sources (Ushasree et al. 2017). Thus, keeping in mind the considerable number of sources and phytase producers, the present study was aimed to use the combination of plate and activity assay for preliminary screening of novel phytase producers from different soil samples from various source locations. The study resulted in potential phytase producing isolates, which can be further characterized and used for various commercial applications.

\section{Materials and methods}

\section{Sample collection}

The samples were collected as per standard protocols published on a national agricultural portal of India (http:// agritech.tnau.ac.in/agriculture/agri_soil_sampling.html). The method involved dividing the field into different units and collecting five samples from each unit by making a ' $V$ ' shaped cut, mixing the soil from each unit in a sterile manner and storing the amalgam in sterile flacons at $4{ }^{\circ} \mathrm{C}$. Eleven sites were chosen from diversified sources, which included a forest area in Ankleshwar (Gujarat), Trikoni Garden in Mumbai (Maharashtra), agricultural fields in Baruch (Gujarat), and swine, poultry as well as other agricultural fields in Jawhar district (Maharashtra) (Table 1). These included soils from forest, garden, and fields with rice, oil seed (Kursani), udad (pulse), nachini, millet (jowar), vegetation (lady finger) and cotton, as well as swine and poultry enclosures. The collected soils were transported to Sunandan Divatia School of Science, NMIMS Deemed to be University, Mumbai in ice boxes, where all further analyses were performed. The soil samples were processed by sieving $(2 \mathrm{~mm})$ to remove litter and lumps. After processing, the soil samples were stored in sterile flacons at $4{ }^{\circ} \mathrm{C}$ until further analysis.

\section{Enrichment, screening and isolation of bacteria}

Phytate degrading microbes were enriched by inoculating $1 \mathrm{~g}$ of processed soil in autoclaved phytase screening broth (PSB) (1\% D-glucose, $0.4 \% \mathrm{Na}$-phytate, $0.2 \% \mathrm{CaCl}_{2}$, $0.5 \% \mathrm{NH}_{4} \mathrm{NO}_{3}, 0.05 \% \mathrm{KCl}, 0.05 \% \mathrm{MgSO}_{4} 7 \mathrm{H}_{2} \mathrm{O}, 0.001 \%$ $\left.\mathrm{FeSO}_{4} 7 \mathrm{H}_{2} \mathrm{O}, 0.001 \% \mathrm{MnSO}_{4} 7 \mathrm{H}_{2} \mathrm{O}\right)$. D-glucose and $\mathrm{Na}$ phytate solutions were filter sterilized and not autoclaved (Kerovuo et al. 1998; Kandil 2017). The inoculated broth was incubated at $180 \mathrm{rpm}$ and $37^{\circ} \mathrm{C}$ on a rotary shaker and screened after $24 \mathrm{~h}$ (day 1) and $120 \mathrm{~h}$ (day 5) on phytase screening agar (PSA) plates. In addition to the ingredients of PSB, $3 \%$ agar was added to prepare the PSA plates. The enriched broths were serially diluted and spread-plated on PSA plates and incubated at room temperature. The colonies that showed zones of hydrolysis similar to those of the wild type E. coli phytase zone were sampled and purified. To obtain pure cultures, colonies from the dilution plates were grown overnight in Luria-Bertani (LB) broth and tryptic soy (TS) broth at $37^{\circ} \mathrm{C}$ and $180 \mathrm{rpm}$ on a rotary shaker. This was followed by streaking of the turbid broths on LB agar plates to obtain pure cultures. 
Table 1. Soil samples collected from different regions of Maharashtra and Gujarat in the winter season and used for isolation of phytaseproducing microorganisms

\begin{tabular}{|c|c|c|c|c|c|}
\hline Soil sample source & Location & $\begin{array}{l}\text { Geographical } \\
\text { coordinates }\end{array}$ & Soil type & Agroecology & Temperature \\
\hline Forest & $\begin{array}{l}\text { Ankleshwar, } \\
\text { Gujrat }\end{array}$ & $\begin{array}{l}21.58102^{\circ} \mathrm{N} \\
73.04682^{\circ} \mathrm{E}\end{array}$ & Forest soil & $\begin{array}{l}\text { Mango, guava, drumstick trees had } \\
\text { grown in a } 24281 \mathrm{~m}^{2} \text { forest land }\end{array}$ & $24^{\circ} \mathrm{C}$ \\
\hline Garden & $\begin{array}{l}\text { Mumbai, } \\
\text { Maharashtra }\end{array}$ & $\begin{array}{l}19.09935^{\circ} \mathrm{N} \\
72.84850^{\circ} \mathrm{E}\end{array}$ & Clay soil & $\begin{array}{l}\text { Roses, Aloe vera, tulsi, herbs, shrubs } \\
\text { were grown in a } 790 \mathrm{~m}^{2} \text { area garden }\end{array}$ & $22^{\circ} \mathrm{C}$ \\
\hline $\begin{array}{l}\text { Rice, oil seed (kursani), } \\
\text { udad (pulse), nachini } \\
\text { (millets) }\end{array}$ & $\begin{array}{l}\text { Jawhar, } \\
\text { Maharashtra }\end{array}$ & $\begin{array}{l}19.91855^{\circ} \mathrm{N} \\
73.23496^{\circ} \mathrm{E}\end{array}$ & $\begin{array}{l}\text { Hill soil (rice, } \\
\text { oil seeed, udad, } \\
\text { nachini) }\end{array}$ & $\begin{array}{l}\text { Rice, oil seeed, udad and nachini were } \\
\text { grown together in a } 4000 \mathrm{~m}^{2} \text { field. The } \\
\text { crops were harvested }\end{array}$ & $26^{\circ} \mathrm{C}$ \\
\hline Swine and poultry & $\begin{array}{l}\text { Jawhar, } \\
\text { Maharashtra }\end{array}$ & $\begin{array}{l}19.91855^{\circ} \mathrm{N} \\
73.23496^{\circ} \mathrm{E}\end{array}$ & $\begin{array}{l}\text { Silt soil (swine, } \\
\text { poultry }\end{array}$ & $\begin{array}{l}\text { The swine and poultry enclosures } \\
\text { were maintained for } 20 \text { and } 4 \text { years, } \\
\text { respectively. Pigs were present during } \\
\text { collection while the chicken were not } \\
\text { present in the poultry since a week }\end{array}$ & $26^{\circ} \mathrm{C}$ \\
\hline $\begin{array}{l}\text { Millets (jowar), } \\
\text { vegetation (lady finger) } \\
\text { and cotton }\end{array}$ & $\begin{array}{l}\text { Baruch, } \\
\text { Gujrat }\end{array}$ & $\begin{array}{l}21.68931^{\circ} \mathrm{N} \\
72.89728^{\circ} \mathrm{E}\end{array}$ & Loam soil & $\begin{array}{l}\text { These crops were grown in } 4047 \mathrm{~m}^{2} \text { land } \\
\text { each. The crops were not harvested }\end{array}$ & $24^{\circ} \mathrm{C}$ \\
\hline
\end{tabular}

\section{Phenotypic identification of bacterial isolates}

All of the isolates were Gram-stained to understand their morphology and physiology and the selected bacterial isolates were further characterized using standard biochemical tests (Table 2; Ramesh et al. 2011; Dev et al. 2016). Biochemical tests included sugar fermentation tests (glucose, sucrose, lactose, maltose and mannitol), growth on MacConkey agar and eosin methylene blue agar, the indole test, methyl red and Voges-Proskauer test, nitrate reduction test, triple sugar iron test, lysine decarboxylase test, citrate test, urease test and catalase test. Gram staining and the biochemical tests were performed in duplicate. Primary bacterial identification was performed using the ABIS online tool (https://www.tgw1916.net/bacteria_ logare_desktop.html) (Dev et al. 2016), which was based on morphology and biochemical properties. Identification of all isolates matched with the sequencing result at genus level, except for FD5T. The isolate was identified as Aneurinibacillus aneurinilyticus by ABIS and Paenibacillus by sequencing.

\section{Qualitative phytase activity}

The two-step counterstaining method adapted from Bae et al. (1999) eliminated false positive results due to acid producing bacteria (Van Staden et al. 2007). The six bacterial isolates and E. coli BL21 (DE3) cultures were spot plated $(10 \mu \mathrm{L})$ on PSA plates and incubated at room temperature for $96 \mathrm{~h}$. After incubation, the PSA plates were flooded with $2 \%(\mathrm{w} / \mathrm{v})$ cobalt chloride solution at room temperature for $5 \mathrm{~min}$. The cobalt chloride solution was then replaced with freshly prepared mixture of $6.25 \%$ $(\mathrm{w} / \mathrm{v})$ aqueous ammonium molybdate and $0.42 \%(\mathrm{w} / \mathrm{v})$ ammonium vanadate solutions $(1: 1, \mathrm{v} / \mathrm{v})$ for 2 to $3 \mathrm{~min}$
(Lee et al. 2005; Park et al. 2012). The zones that did not regain turbidity and remained colourless were considered to be phytase producing positive isolates. The qualitative analysis was done in duplicate.

\section{Molecular identification of bacterial isolates}

Genomic DNA of the 6 putative phytase producers was isolated using the PureLink ${ }^{\circledR}$ Genomic DNA kit, following the manufacturer's protocol. The DNA isolates were quantified and checked for their purity on BioTek nanoplates using BioTek Gen5 software. PCR amplification of $16 \mathrm{~s}$ rDNA gene was performed in duplicate using forward primer 151F (5'-GTGCCAGCMGCCGCGGTAA-3') and reverse primer Y36 (5'-GAAGGAGGTGWTCCADCC-3') under the following conditions: 30 cycles of initial denaturation at $95^{\circ} \mathrm{C}$ for $3 \mathrm{~min}$, denaturation at $95^{\circ} \mathrm{C}$ for $45 \mathrm{~s}$, annealing at $54^{\circ} \mathrm{C}$ for $30 \mathrm{~s}$, initial extension at $72^{\circ} \mathrm{C}$ for $1 \mathrm{~min} 30 \mathrm{~s}$ and final extension at $72^{\circ} \mathrm{C}$ for $10 \mathrm{~min}$. The PCR products of the samples were digested with MspI (HpaII) restriction enzymes to carry out restriction fragment length polymorphism (RFLP) and the products were run on a $3 \%$ agarose gel. This process was carried out in duplicate. The shortlisted phytase producers were identified at species level via $16 \mathrm{~s}$ rDNA sequencing using universal primers. The sequences were analysed on the NCBI database using blastn, and the 16s rDNA sequences of the species with the highest homology were extracted for in silico RFLP and phylogenetic analysis. In silico RFLP was performed on the sequenced sample data along with the extracted $16 s$ rDNA of the homologous species on the Serial Cloner 2.6.1.0 software using the same restriction endonucleases. A neighbour-joining dendrogram with 1000 bootstrap testing was constructed using MEGA X 10.2.2 software 
Table 2. Standard protocol followed for performing the biochemical tests of isolates from different soils. As a sample, 24-h-old isolated colonies suspended in sterile saline was used in all tests

\begin{tabular}{|c|c|c|}
\hline Test & Reagents & Procedure \\
\hline $\begin{array}{l}\text { Sugar } \\
\text { fermentation } \\
\text { test }\end{array}$ & $\begin{array}{l}\text { - sterile peptone water, } \\
\text { - } 0.2 \% \text { phenol red, } \\
\text { - } 1 \% \text { of glucose, lactose, sucrose, maltose } \\
\text { and mannitol, } \\
\text { glassware: Durham's tubes }\end{array}$ & $\begin{array}{l}\text { - To the peptone water, } 0.2 \% \text { phenol red was added and Durham's tube } \\
\text { was inverted and then the test tubes were autoclaved. } \\
\text { - } 1 \% \text { of each sugar was added to the autoclaved set up. } \\
\text { - Aseptically the samples were inoculated and incubated at } 37^{\circ} \mathrm{C} \text { for } 24 \mathrm{~h}\end{array}$ \\
\hline Indole test & $\begin{array}{l}\text { - sterile peptone water, } \\
\text { - Kovac's reagent }\end{array}$ & $\begin{array}{l}\text { - To the sterilized peptone water, the samples were inoculated and } \\
\text { incubated at } 37^{\circ} \mathrm{C} \text { for } 24 \mathrm{~h} \text {. } \\
\text { - } 4 \text { to } 5 \text { drops of Kovac's reagent was added to the tube from the walls } \\
\text { gently to form a red colored ring }\end{array}$ \\
\hline $\begin{array}{l}\text { Methyl red } \\
\text { test }\end{array}$ & $\begin{array}{l}\text { - sterile buffered glucose phosphate broth, } \\
\text { - methyl red }\end{array}$ & $\begin{array}{l}\text { - To the sterilized broth, the samples were inoculated and incubated at } 37 \\
{ }^{\circ} \mathrm{C} \text { for } 24 \mathrm{~h} \text {. } \\
\text { - } 4 \text { to } 5 \text { drops of Methyl red indicator were added and observed for } \\
\text { colour change }\end{array}$ \\
\hline $\begin{array}{l}\text { Voges- } \\
\text { Proskauer test }\end{array}$ & $\begin{array}{l}\text { - sterile buffered glucose phosphate broth, } \\
\text { - a-naphthol, } \\
\text { - } 40 \% \mathrm{KOH}\end{array}$ & $\begin{array}{l}\text { - To the sterilized broth, the samples were inoculated and incubated at } 37 \\
{ }^{\circ} \mathrm{C} \text { for } 24 \mathrm{~h} \text {. } \\
\text { - } 5 \text { to } 6 \text { drops of } \alpha \text {-naphthol and } 2 \text { to } 3 \text { drops of } \mathrm{KOH} \text { were added and } \\
\text { observed for colour change }\end{array}$ \\
\hline $\begin{array}{l}\text { Citrate } \\
\text { utilization } \\
\text { test }\end{array}$ & - sterile Simmon's citrate agar & $\begin{array}{l}\text { - To the solidified agar, the samples were streaked and incubated at } 37^{\circ} \mathrm{C} \\
\text { for } 24 \mathrm{~h} \text {. } \\
\text { - Observed for colour change }\end{array}$ \\
\hline Urease test & $\begin{array}{l}\text { - sterile Christensen's agar, } \\
\text { - urea }\end{array}$ & $\begin{array}{l}\text { - Urea was added aseptically to the autoclaved melted agar and then } \\
\text { solidified. } \\
\text { - To the solidified agar, the samples were streaked and incubated at } 37^{\circ} \mathrm{C} \\
\text { for } 24 \mathrm{~h} \text {. } \\
\text { - Observed for colour change }\end{array}$ \\
\hline $\begin{array}{l}\text { Nitrate } \\
\text { reduction test }\end{array}$ & $\begin{array}{l}\text { - sterile nitrate broth, } \\
\text { - sulphanilic acid, } \\
\text { - } a \text { - naphthylamine }\end{array}$ & $\begin{array}{l}\text { - To the sterilized broth, the samples were inoculated and incubated at } 37 \\
{ }^{\circ} \mathrm{C} \text { for } 24 \mathrm{~h} \text {. } \\
\text { - } 4 \text { to } 5 \text { drops of sulphanilic acid and } 4 \text { to } 5 \text { drops of } \text {-naphthylamine } \\
\text { were added and observed for colour change }\end{array}$ \\
\hline $\begin{array}{l}\text { Triple sugar } \\
\text { iron agar test }\end{array}$ & - sterile triple sugar agar & $\begin{array}{l}\text { - To the solidified agar, the samples were streaked and incubated at } 37^{\circ} \mathrm{C} \\
\text { for } 24 \mathrm{~h} \text {. } \\
\text { - Observed for colour change }\end{array}$ \\
\hline $\begin{array}{l}\text { Lysine } \\
\text { decarboxylase } \\
\text { test }\end{array}$ & $\begin{array}{l}\text { - sterile Moeller's medium, } \\
\text { - paraffin oil }\end{array}$ & $\begin{array}{l}\text { - To the sterilized media, the samples were inoculated, overlaid with } \\
\text { paraffin oil and incubated at } 37^{\circ} \mathrm{C} \text { for } 24 \mathrm{~h} \text {. } \\
\text { - Observed for colour change }\end{array}$ \\
\hline Catalase test & - hydrogen peroxide solution & $\begin{array}{l}\text { - The culture was spread on a clean glass slide and } 2 \text { to } 3 \text { drops of } \mathrm{H}_{2} \mathrm{O}_{2} \\
\text { were added. } \\
\text { - Observed for presence of bubbles }\end{array}$ \\
\hline
\end{tabular}

by clustering the obtained sample sequencing results with the extracted $16 \mathrm{~s}$ rDNA sequence exploited in the in silico analysis.

\section{Quantitative effect of $\mathrm{pH}$ on phytase activity}

The phytase activity was estimated using glycine- $\mathrm{HCl}(\mathrm{pH}$ 2.5) and sodium acetate ( $\mathrm{pH} 5$ ) buffer systems. The isolates did not exhibit any detectable activity in the alkaline $\mathrm{pH}$ range of Tris- $\mathrm{HCl}$ buffer ( $\mathrm{pH}$ 7.5). Potassium dihydrogen phosphate $\left(\mathrm{KH}_{2} \mathrm{PO}_{4}\right)$ was used for inorganic phosphate standardization at concentrations $0.1 \mathrm{mM}$ to $2 \mathrm{mM}$. Sodium phytate (44 mM stock) was used as substrate at 1:50 dilution in the respective buffer systems. The colour reagent solution was freshly prepared to terminate the reaction using 5\% ammonium molybdate, $100 \%$ acetone, $5 \mathrm{~N}$ sulphuric acid (1:2:1). After incubation for $30 \mathrm{~min}$ at $37^{\circ} \mathrm{C}$ in a water bath, the phosphate released from sodium phytate hydrolysis was measured using the ammonium molybdate method, which is a modification of the Heinonen method (Suleimanova et al. 2015). The final reaction volume was 1 
$\mathrm{mL}$ and performed in duplicate. To remove any turbidity that might remain after incubation, the reaction solution was centrifuged at $14000 \mathrm{rpm}, 25^{\circ} \mathrm{C}$ for $5 \mathrm{~min}$. One unit of phytase activity $\left(\mathrm{U} \mathrm{mL}^{-1}\right)$ was defined as the amount of phytase enzyme required to liberate $1 \mathrm{mmol}$ of inorganic phosphate per minute by utilizing sodium phytate as the substrate under assay conditions.

To estimate the activity of intracellular phytase, $1 \mathrm{~mL}$ of overnight grown soil isolate cultures, in Luria-Bertani broth, were aliquoted and the cells were harvested at 10000 $\mathrm{rpm}, 25^{\circ} \mathrm{C}$ for $10 \mathrm{~min}$. Cells were lysed using B-cell lysis buffer (Sigma-Aldrich) and the freeze thaw method in the presence of $2 \%$ phenylmethylsulfonyl fluoride as the protease inhibitor. The lysate was collected by centrifugation at $10000 \mathrm{rpm}, 4^{\circ} \mathrm{C}$ for $10 \mathrm{~min}$, discarding the pellet. The crude extract was used for measuring intracellular activity. The blanks that were set up were a substrate blank, enzyme blank and combination blank (reaction in which substrate and supernatant were not added). Bovine serum albumin stock $\left(10 \mu \mathrm{g} \mu \mathrm{L}^{-1}\right)$ was used for protein standardization at concentrations 0.2 to $10 \mu \mathrm{g} \mu \mathrm{L}^{-1}$.

Extracellular activity was also measured by checking activity in supernatant of $24 \mathrm{~h}$ grown cultures, but the isolates did not show any detectable extracellular activity.

\section{Statistical analysis}

The statistical significance of differences was determined by Student's $t$-tests followed by two-way ANOVA using the GraphPad Prism 9.0.0 software. For the comparison of the mean values, a $5 \%$ level of significance was considered.

\section{Results}

\section{Enrichment, screening and isolation of bacteria}

All eleven soil samples were enriched in PSB for $24 \mathrm{~h}$ (day 2 broths) followed by screening on sterile PSA plates. After $120 \mathrm{~h}$ (day 5 broths) of enrichment udad, nachini, millets, rice and oil seed samples were excluded from screening to due fungal overgrowth, leaving only six samples (forest, garden, swine and poultry enclosures, and vegetation and cotton fields) which were screened on PSA plates. The screening plates were observed after 24, 48 and $96 \mathrm{~h}$. From the plates of the day 2 broth samples, only forest, swine enclosure and vegetation soil samples showed prominent halo zones after $24 \mathrm{~h}$. At $48 \mathrm{~h}$, garden plates also had decreased turbidity and increased growth of colonies. A few plates had filamentous fungal growth. All of the 96-h plates had excessive fungal growth and increased number of colonies in the lower dilution plates. Due to no halo zone on plates for day 2 broths of oil seed, cotton, udad, rice, millets and nachini field samples, they were eliminated and not used for bacterial isolation. Plating of the day 5 broths was done at dilution $10^{-3}$ due to excessive crowding in $10^{-1}$ and $10^{-2}$ dilutions in plates of day 2 broths. Dilutions higher than $10^{-5}$ were prepared for the samples that required more scattered colonies. Oil seed, udad, rice, millets and nachini soil samples continued to not show a zone of hydrolysis and were hence eliminated.

Higher dilutions were used for further isolations. Isolation was done by sampling colonies from the $96 \mathrm{~h}$ plates on the basis of presence of a zone of hydrolysis around the colony. After screening, samples used for further isolation were broth plates (day 5) for cotton and broth plates (day 2 and day 5) for forest, garden, vegetation, and swine and poultry enclosure soil samples. The colonies were grown overnight in LB broth and TS broth followed by isolation on LB agar. Translucent and large colonies as well as opaque and small colonies were observed and further isolated for the forest sample on LB agar. The swine enclosure sample plate that was streaked from TS broth showed mucoid like colonies while all the other remaining sample plates had creamy and opaque colonies regardless of the broth from which LB agar plates were streaked. The isolates were named on the basis of the soil source (C, F, G, V, PS, P), the enrichment broth isolated from (D2, D5), the opacity (O, $\mathrm{T}$ ) and the broth from which LB agar was streaked (LB, TS).

\section{Phenotypic identification of bacterial isolates}

Gram staining was used to identify the morphology and Gram nature. A total of thirteen isolated colonies from the LB agar were analysed. The samples GD2, GD5, VD2, PSD2, PSD5LB, PD2, and PD5 showed a bean shaped structure and were suspected to be yeast cultures, and were therefore eliminated. VD5, CD5 and PSD5TSB were Gram-negative bacteria and FD2, FD5T and FD5O were Gram-positive bacteria, which were confirmed by examining the growth on MacConkey agar and eosin methylene blue agar. The remaining six samples were biochemically characterized (Table 3). From the online ABIS tool the isolates were identified as Aneurinibacillus aneurinilyticus (FD5T), Bacillus carboniphilus (FD5O and FD2), Enterobacter amnigenus (VD5 and CD5), and Raoultella terrigena (PSD5TSB).

\section{Qualitative phytase activity}

Qualitative analysis of phytate degrading bacteria was done by differential staining. After the two-step staining process, the halos around the colonies remained colourless validating that the samples were true phytase producers and not acid producers. The amount of secreted phytase that led to the halo formation was measured in comparison to wild type E. coli BL21 (DE3). The PSD5TSB zone was greater than for E. coli and FD5O had similar zone size as E. coli. The remaining samples had zones smaller than the control (Table 4). This step along with the screening step confirmed the produced phytase as well as identified the bacterial samples that produced phytase but without any measurable activity. This method served as initial screening and identification method for phytase producing bacteria, but an additional rapid procedure of testing for intracellular enzyme activity was performed at a small scale. 
Table 3. Results of biochemical tests of isolates FD5T, FD2, FD5O, PSD5TSB, VD5 and CD5. +, positive; -, negative; Y, yellow; Pi, pink; $\mathrm{C}$, colourless; $\mathrm{Pu}$, purple

\begin{tabular}{|c|c|c|c|c|c|c|c|}
\hline \multirow[t]{2}{*}{ Tests } & \multirow[t]{2}{*}{ Indication } & \multicolumn{6}{|c|}{ Isolate } \\
\hline & & FD5T & FD5O & FD2 & VD5 & CD5 & PSD5TSB \\
\hline \multirow[t]{2}{*}{ Glucose } & Colour & - & - & - & + & + & + \\
\hline & Gas & - & - & - & + & + & + \\
\hline \multirow[t]{2}{*}{ Maltose } & Colour & - & - & - & + & + & + \\
\hline & Gas & - & - & - & + & + & + \\
\hline \multirow[t]{2}{*}{ Lactose } & Colour & - & - & - & - & - & + \\
\hline & Gas & - & - & - & - & - & + \\
\hline \multirow[t]{2}{*}{ Sucrose } & Colour & - & - & - & + & + & - \\
\hline & Gas & - & - & - & + & + & + \\
\hline \multirow[t]{2}{*}{ Mannitol } & Colour & - & - & - & + & + & + \\
\hline & Gas & - & - & - & + & + & + \\
\hline \multicolumn{2}{|l|}{ MacConkey agar } & - & - & - & $+\mathrm{Y}$ &,$+ \mathrm{Y}$ & + Pi (mucoid) \\
\hline \multicolumn{2}{|c|}{ Eosin methylene blue agar } & - & - & - & $+\mathrm{C}$ &,$+ \mathrm{C}$ & $+\mathrm{Pu}$ (mucoid) \\
\hline \multicolumn{2}{|l|}{ Indole } & - & - & - & - & - & - \\
\hline \multicolumn{2}{|l|}{ Methyl red } & + & - & - & - & - & - \\
\hline \multicolumn{2}{|l|}{ Voges-Proskauer } & + & + & + & + & + & + \\
\hline \multicolumn{2}{|l|}{ Nitrate reduction } & + & - & - & + & + & + \\
\hline \multirow[t]{4}{*}{ Triple sugar iron } & Butt & $\mathrm{Y}$ & $\mathrm{Y}$ & $\mathrm{Y}$ & $\mathrm{Y}$ & $\mathrm{Y}$ & $\mathrm{Y}$ \\
\hline & Slant & $\mathrm{Y}$ & $\mathrm{Y}$ & $\mathrm{Y}$ & $\mathrm{Y}$ & $\mathrm{Y}$ & $\mathrm{Y}$ \\
\hline & Gas & - & - & - & + & + & + \\
\hline & $\mathrm{H}_{2} \mathrm{~S}$ & - & - & - & - & - & - \\
\hline \multicolumn{2}{|c|}{ Lysine decarboxylase } & - & - & - & - & - & + \\
\hline \multicolumn{2}{|l|}{ Citrate } & - & - & - & $\mathrm{Y}$ & $\mathrm{Y}$ & $\mathrm{Y}$ \\
\hline \multicolumn{2}{|l|}{ Urease } & - & - & - & - & - & - \\
\hline \multicolumn{2}{|l|}{ Catalase } & - & + & + & + & + & + \\
\hline
\end{tabular}

\section{Molecular identification of bacterial isolates}

The gDNA of overnight grown FD5T, FD5O, FD2, VD5, CD5 and PSD5TSB samples was isolated using a PureLink ${ }^{\otimes}$ Genomic DNA kit. The size of isolated gDNA was greater than $10 \mathrm{~kb}$. The quantity and quality of the isolated DNA of samples were measured by nanoplate UV transmission (Table 5). PSD5TSB had the highest concentration of extracted gDNA among the samples. Amplification of the $16 \mathrm{~s}$ rDNA of the genome was done using universal primers, $151 \mathrm{~F}$ as the forward primer and $\mathrm{Y} 36$ as the reverse primer. The $1 \mathrm{~kb}$ PCR amplicon was amplified and resolved on an agarose gel.

Table 4. The diameters of the halo zones formed by the isolates (FD5T, FD2, FD5O, PSD5TSB, VD5, CD5) and wildtype E. coli BL21 (DE3) on counter-stained PSA plates

\begin{tabular}{|lc|}
\hline Isolate & Zone of hydrolysis $(\mathbf{m m})$ \\
\hline FD5T & 10 \\
\hline PSD5TSB & 14 \\
\hline CD5 & 9 \\
\hline FD5O & 12 \\
\hline FD2 & 11 \\
VD5 & 8 \\
\hline Wild type E. coli & 13
\end{tabular}

RFLP was performed on amplified 16s rDNA product using MspI (HpaII) enzymes. PSD5TSB, VD5 and CD5 had similar band patterns, which was also observed for FD5O and FD2. FD5T showed a different pattern from the other samples. In silico RFLP analysis of the sequenced data showed a similar number of bands with the same band size as those of the agarose gel, validating the performed RFLP. The in silico comparison of the sequenced data band pattern with those of the extracted species sequence showed similarity, which indicated that the species identification could be correct. Species level identification of the unknown samples was done by 16 sDNA sequencing. The

Table 5. Nanodrop quantification and qualification of isolated gDNA from phytase-producing bacteria (FD5T, FD2, FD5O, PSD5TSB, VD5, CD5)

\begin{tabular}{lcc} 
Isolate & $\begin{array}{c}\text { Concentration of } \\
\text { DNA }\left(\mathbf{n g} \boldsymbol{\mu L} \mathbf{L}^{-1}\right)\end{array}$ & $\mathbf{A}_{\mathbf{2 6 0}} / \mathbf{A}_{\mathbf{2 8 0}}$ ratio \\
FD5T & 19.773 & 1.985 \\
\hline PSD5TSB & 140.446 & 1.507 \\
CD5 & 85.607 & 1.847 \\
\hline FD5O & 9.053 & 1.517 \\
FD2 & 12.349 & 1.914 \\
VD5 & 112.757 & 1.946
\end{tabular}


samples were submitted for sequencing and were identified as Enterobacter cloacae (VD5 and CD5), Paenibacillus sp. (FD5T), Bacillus megaterium (FD5O and FD2), Klebsiella variicola (PSD5TSB). VD5 and CD5 were 99.2 and $99.6 \%$ identical to Enterobacter cloacae respectively (GenBank Accession no. CP046116.1, E value 0), FD5T was 98.37\% identical to Paenibacillus sp. (GenBank Accession no. MK681944.1, Evalue 0), FD5O and FD2 were 99.4 and 99.2\% identical to Bacillus megaterium, respectively (GenBank Accession no. CP045272.1, E value 0), and PSD5TSB was 99.4\% identical to Klebsiella variicola (GenBank Accession no. CP050958.1, E value 0). A phylogenetic tree for the six samples was built based on homology of the 16s rDNA sequence (Fig. 1). CD5 and VD5 were closely clustered with Enterobacter cloacae strain ATCC 13047, PSD5TSB was in the same cluster as Klebsiella aerogenes KCTC 2190, FD5T was in the same cluster as Paenibacillus yonginensis strain DCY84 and FD5O along with FD2 was clustered with Bacillus sp. 3401BRRJ. PSD5TSB, CD5 and VD5 were closely related, which was portrayed in the phenotypic identification as well as RFLP analysis. Paenibacillus sp. (FD5T) had very close similarity to Paenibacillus yonginensis 16s rDNA. The dendrogram showed that there was similarity between Bacillus sp. and Paenibacillus sp. strains.

\section{Quantitative effect of $\mathrm{pH}$ on phytase activity}

Intracellular phytase enzyme activity and protein estimation were detected using the Heinonen method with $\mathrm{pH}$ as the limiting factor. The $R^{2}$ values were close to 1 , indicating that the values obtained for the concentration of inorganic phosphate and protein concentration were acceptable. All of the readings were taken in duplicate with standard deviation close to 0 between the duplicates. The wild type E. coli phytase was used as a standard to confirm phytase activity. At pH 2.5, E. coli phytase showed an average of 135 times more activity than FD5T, PSD5TSB, CD5 and VD5 while FD5O and FD2 showed no activity at this $\mathrm{pH}$. On the other hand, there was a significant decrease in activity of $E$. coli phytase at pH 5. PSD5TSB, CD5, FD5O, FD2 and VD5 and FD5T had higher activity at $\mathrm{pH} 5$ as compared to $\mathrm{pH}$ 2.5. At pH 7.5, all samples including E. coli had a small amount of inorganic phosphate liberated, which could not be detected using the assay. E. coli had highest activity at $\mathrm{pH}$ 2.5 while the unknown samples had highest activity at $\mathrm{pH} 5$ (Fig. 2). This technique aided in inferring the optimum $\mathrm{pH}$ for phytase samples on a small scale. Furthermore, it helped in narrowing down and identifying the samples that had intracellular activity comparable with the standard. Hence, these were further analysed and examined for large scale characterization.

To compare the intracellular and extracellular activity of the phytase enzyme, the reaction mixtures for extracellular activity were prepared in the same manner as that of intracellular testing with the use of the three $\mathrm{pH}$ buffers. The isolates were grown in PSB for $24 \mathrm{~h}$ and the supernatant was used as the phytase sample and checked for extracellular activity. $\mathrm{KH}_{2} \mathrm{PO}_{4}$ standard curves were prepared and had $R^{2}$ values close to 1 . All of the unknown samples had undetectable amounts of liberated inorganic phosphate, while the E. coli sample had a significant amount of extracellular activity in the three $\mathrm{pH}$ buffers. Hence, the samples expressed only intracellular phytase with measurable activity.

\section{Discussion}

Phytase is a class of phosphatase and the respective bacteria are frequently termed as phosphate-solubilizing bacteria, which are a type of plant growth promoting bacteria (Igual et al. 2001). Phosphorus is an essential macronutrient. Phytate is the predominant form of organic P present in soil. Plants cannot utilize phytate directly and it needs to be mineralized by phytase enzyme (Singh et al. 2014; Suleimanova et al. 2015; Motamedi 2016; Alori et al. 2017; Caffaro et al. 2019). Hence, phosphate-solubilizing bacteria are found in the rhizosphere of crops that grow in P-rich soil (Singh et al. 2014; Caffaro et al. 2019). The

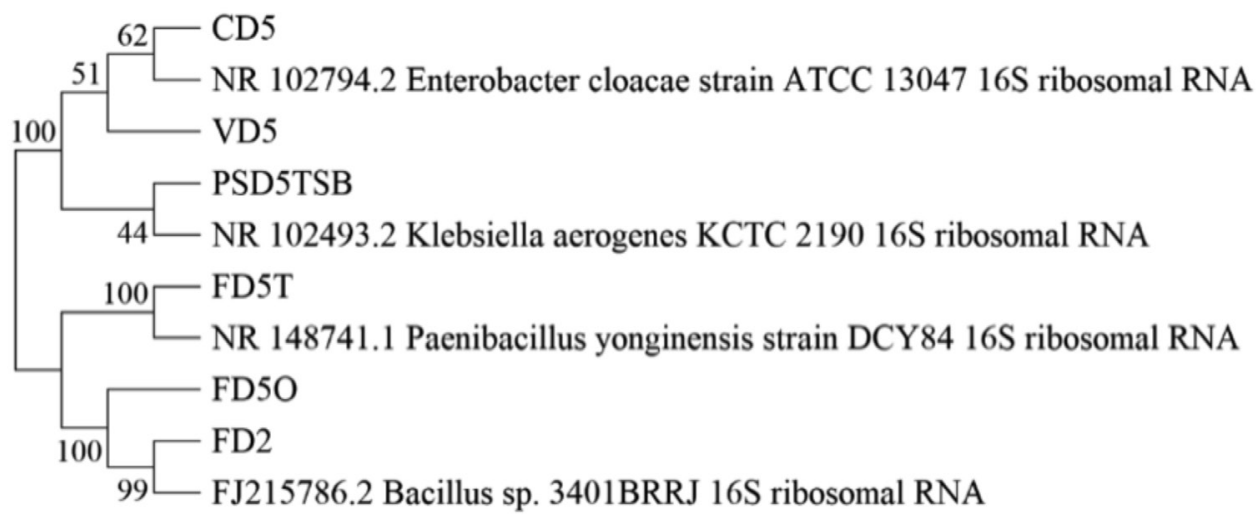

Fig. 1. Neighbor-joining dendrogram showing the relation between the samples (FD5T, FD2, FD5O, PSD5TSB, VD5, CD5) and the 16s rDNA of their closest related strains (Enterobacter cloacae strain ATCC 13047, Klebsiella aerogenes KCTC 2190, Paenibacillus yonginensis strain DCY84 and Bacillus sp. 3401BRRJ) obtained from GenBank. The tree was constructed by 1000 bootstrap tests. 


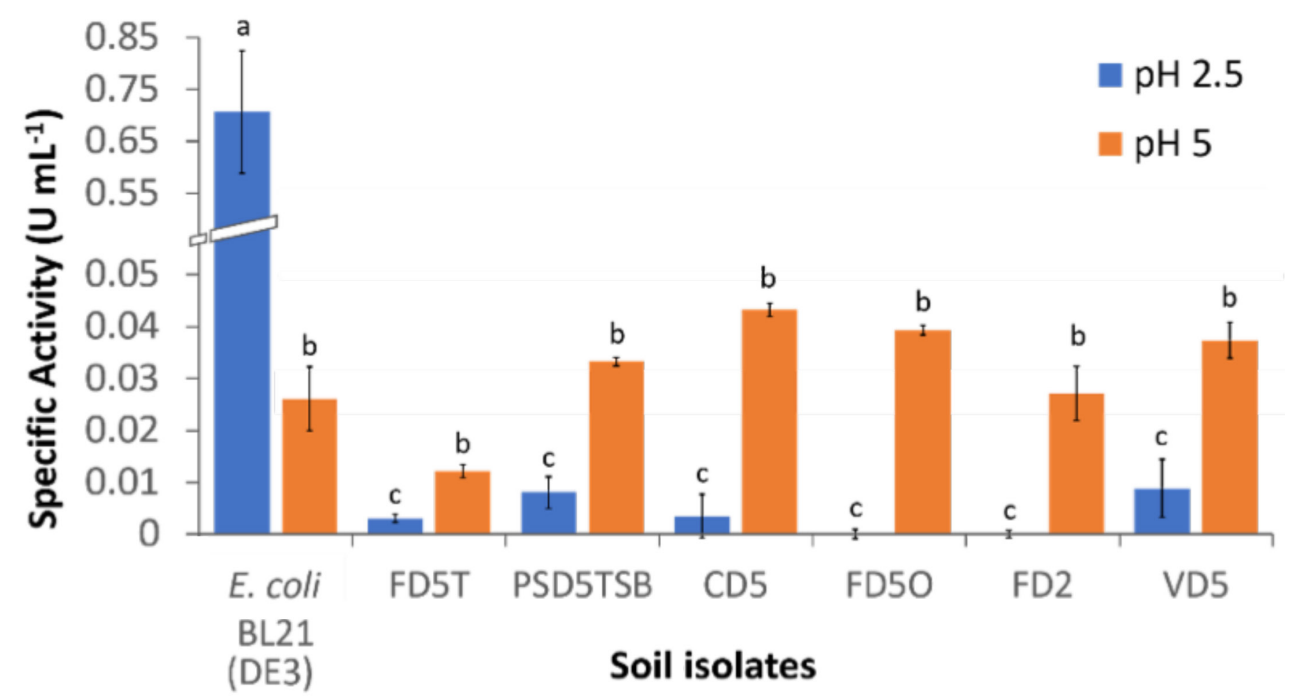

Fig. 2. Comparison of intracellular specific activity at $\mathrm{pH} 2.5 \mathrm{pH} 5$ of phytase from the samples (FD5T, FD2, FD5O, PSD5TSB, VD5, CD5) with wildtype E. coli BL21 (DE3) phytase as the positive control. The samples had no activity at pH 7.5. Data is shown as mean \pm standard error $\left(\mathrm{U} \mathrm{mL}^{-1}\right)$. Statistical significance was estimated by Student's $t$-test and two-way ANOVA at $p \leq 0.05$. The letters depict the significant difference in mean for each soil isolate at $\mathrm{pH} 2.5$ and $\mathrm{pH} 5$ as well as the difference across the soil isolates in their respective $\mathrm{pH}$.

intestinal microbiota in monogastric animals is devoid of species secreting phytase, leading to unutilized phytate in the gut. Phytase is thus excreted and found in enough concentration for the phytase-producing bacteria to thrive (Mittal et al. 2011). Thus, phytase-producing bacteria are not only found in the rhizospheric soil of grain, legume, nut, oil seed crops (Dahiya 2016), but also found in soil around monogastric animal shelters (Caffaro et al. 2019). A wide range of organisms (fungi, bacteria, yeast, plants and animals) are known to express phytase (Li et al. 2019).

Phenotypic identification of bacteria by standard methods of morphological and biochemical characterization has been a key step for many years in studies on phytase producing bacteria such as Bacillus sp., Achromobacter sp., Tetrathiobacter sp., Klebsiella sp. (Tye et al. 2002; Roy et al. 2009; Mittal et al. 2011; Khan, Ghosh 2012; Kumar et al. 2013). In recent years, this traditional method has been applied for primary identification of phytase producers like Acinetobacter sp., Enterobacter sp., several Bacillus sp. and Lactobacillus sp. (Ibnu Irwan et al. 2017; Alias et al. 2018; Muslim et al. 2018; Onipede et al. 2020). While these studies have biochemically identified the species using the Bergey's manual, an upcoming online tool, ABIS, has shown promising results in species level identification (Rahman et al. 2017; Stoica, Sorescu 2017; Siddque, Alif 2018; Guder, Krishna 2019). In the present study, primary identification of Bacillus carboniphilus (FD5O and FD2), Enterobacter amnigenus (VD5 and CD5), Raoultella terrigena (PSD5TSB) and Aneurinibacillus aneurinilyticus (FD5T) from the six samples was made based on their Gram-nature and biochemical character.

Phytate degrading bacteria such as Serratia sp.,
Enterobacter sp., Paenibacillus sp., Bacillus sp., Lactobacillus sp., Geobacillus sp. can be derived from diverse sources from rhizospheric soil, compost, poultry farms, cattle shade, fermented foods, volcanic ash and geysers (Jorquera et al. 2011; Singh et al. 2013; Sajidan et al. 2015; Kalsi et al. 2016; Savita et al. 2017; Jorquera et al. 2018). These studies, among many others, screened various samples on PSA for visualization of the zone of hydrolysis and studies were continued with sample that showed a satisfactory halo zone. Nonetheless, these zones around colonies can be false positive due to acid-producing bacteria for which the counterstaining step has to be used (Chanderman et al. 2016; Monika et al. 2017; Nasrabadi et al. 2018). Bacteria from forest (FD2, FD5O, FD5T), vegetation (VD5), cotton (CD5) and pig enclosure (PSD5TSB) soil samples were all isolated after screening on PSA for the presence of a halo zone, and were then confirmed as true phytase producers by qualitative analysis. From the eleven soil samples, oil seed, udad, rice, millets and nachini samples were eliminated due to lack of a halo zone, which aided in narrowing down the samples and saving resources for further analysis. E. coli is known to have high phytase activity against phytate and therefore was used as a positive control (Helian et al. 2020).

RFLP is a molecular technique for identification of the bacterial isolates, which is cost effective, fast and can be repeated again (Miao et al. 2013). This fingerprinting technique based on the 16s rDNA part of the genome has been used to study the microbial diversity present in several habitats (Kushwaha et al. 2020). While there have been few studies performing 16s rDNA RFLP procedures for initial identification of phytase expressing bacteria in recent years, this quick method helped in visually 
identifying and assessing the variability of the phytase producers, as was done for Pseudomonas sp., Acinetobacter sp., Agrobacterium sp. and Arthrobacter sp., among many other species (Sanguin et al. 2016). In the current study, by comparing the pattern of resolution on the gel, RFLP results showed that there were four different species of isolated bacteria. This was confirmed by in silico testing and ultimately sequencing showing that FD2 and FD5O were Bacillus megaterium, FD5T was Paenibacillus sp., VD5 and CD5 were Enterobacter cloacae, and PSD5TSB was Klebsiella variicola.

For intracellular activity analysis, the BRENDA enzyme database (www.brenda-enzymes.org) provided concise kinetics of enzymes (Jeske et al. 2019) and indicated the optimal pH of phytase producing bacteria (EC 3.1.3.8). Bacillus sp. express $\beta$-propeller phytase (also known as alkaline phytase), which is dependent on $\mathrm{Ca}^{2+}$ as a cofactor for its activity at alkaline $\mathrm{pH}$, while remaining inactive at acidic pH (Tran et al. 2011a; Tran et al. 2011b). FD5O and FD2 were Bacillus megaterium, which produces $\beta$-propeller phytase (Kumar et al. 2017). This phytase was rendered inactive due to the absence of a source of calcium in the reaction set up. Paenibacillus sp. are also alkaline phytase producers, which remain inactive at acidic $\mathrm{pH}$ (Kumar et al. 2017). A Paenibacillus sp. was characterized with optimal activity towards $\mathrm{pH} 5$ and almost no activity at pH 7 (Acuña et al. 2011). Enterobacter cloacae (VD5 and CD5) and Klebsiella variicola (PSD5TSB) had optimal phytase activity at $\mathrm{pH}$ 5. The $\mathrm{pH}$ range for Enterobacter sp., which was isolated from the rhizosphere, was reported to be $\mathrm{pH} 2$ to 6 (Chanderman et al. 2016), indicating no activity toward alkaline $\mathrm{pH}$. In studies conducted on effect of $\mathrm{pH}$, Enterobacter cloacae showed highest activity at $\mathrm{pH} 5$ (Suliasih, Widawati 2020). Different Klebsiella sp. have shown optimum activity at $\mathrm{pH} 5$ (Sajidan et al. 2004; Elkhalil et al. 2007), with Klebsiella variicola having reduced activity at pH 7 (López Ortega et al. 2013). E. coli enzyme, which is categorized as histidine acid phytase, had higher activity towards an acidic $\mathrm{pH}$ (Okamoto et al. 2017; Balaban et al. 2018). The phytase of E. coli BL21 (DE3) and identified isolates showed no activity at alkaline $\mathrm{pH}$ 7.5. At $\mathrm{pH} 2.5$, E. coli showed an average of 135 times more activity than FD5T, PSD5TSB, CD5, and VD5 while FD5O and FD2 showed no activity at this $\mathrm{pH}$. On the other hand, there was a significant decrease of activity of $E$. coli at $\mathrm{pH} 5$ as compared to $\mathrm{pH}$ 2.5. PSD5TSB, CD5, FD5O, FD2 and VD5 had slightly higher activity than $E$. coli while FD5T did not show much improvement from $\mathrm{pH} 2.5$ to $\mathrm{pH} 5$.

Studies with phytases from Bacillus megaterium (D. Kumar et al.2013), Paenibacillus sp. (Khianngam et al.2017), Enterobacter cloacae (Onawola et al. 2019) and Klebsiella variicola (López Ortega et al. 2013) have shown that for significant detection of extracellular phytase secreted in the media, a minimum of $48 \mathrm{~h}$ of incubation is required. The optimal incubation time for $E$. coli phytase production was determined to be $48 \mathrm{~h}$, but it also had measurable activity after $24 \mathrm{~h}$ (Wang et al. 2015). The current study quantified phytase only after $24 \mathrm{~h}$. During this period, apart from $E$. coli, substantial phytase was not secreted by the soil isolates and hence not detected by the assay. On the basis of these data, the isolated bacteria have great potential to excrete phytase after sufficient incubation and further condition optimization.

Preliminary screening of phytase producing bacteria by analyzing the zone of hydrolysis is a commonly used method. In this study, intracellular activity was also determined to accurately narrow down the number of samples and confirm the presence of phytase. At a mini-scale, these techniques provide higher confidence for further analysis, which occurs at a larger scale using phytase purification and characterization. The ability to solubilize phosphate is not specific to a single genera (Motamedi 2016). Due to high soil microbial diversity (Kumar et al. 2016), implementing preliminary screening reduces additional costs and resources of large scale experimentation on a large number of isolates. Therefore, this study shows an alternative at a mini scale to acquire effective bacterial phytase producers.

\section{Acknowledgements}

The authors would like to acknowledge Sunandan Divatia School of Science, NMIMS Deemed to be University, Mumbai, India for providing the opportunity and the resources for the project research. The authors also want to thank Ms. Rajvi Shah and Ms. Freyan Vakharia for their contributions in the research work. Authors would like to give special thanks to Mr. Mitesh Joshi and Ms. Shriya Sawant for their intellectual inputs and suggestions at various points in the research.

\section{References}

Acuña J.J., Jorquera M.A., Martínez O.A., Menezes-Blackburn D., Fernández M.T., Marschner P., Greiner R., Mora M.L. 2011. Indole acetic acid and phytase activity produced by rhizosphere bacilli as affected by $\mathrm{pH}$ and metals. J. Soil Sci. Plant Nutr. 11: 1-12.

Akhmetova A.I., Nyamsuren C., Balaban N.P., Sharipova M.R. 2013. Isolation and characterization of a new bacillary phytase. Russ. J. Bioor. Chem. 39: 384-389.

Alias N., Shunmugam S., Ong P.Y. 2018. Isolation and molecular characterization of phytase producing bacteria from Malaysia hot springs. J. Fund. Appl. Sci. 9: 852-865.

Alori E.T., Glick B.R., Babalola O.O. 2017. Microbial phosphorus solubilization and its potential for use in sustainable agriculture. Front. Microbiol. 8: 1-8.

Bae H.D., Yanke L.J., Cheng K.J., Selinger L.B. 1999. A novel staining method for detecting phytase activity. J. Microbiol. Meth. 39: 17-22.

Bajaj B.K., Wani M.A. 2015. Purification and characterization of a novel phytase from Nocardia sp. MB 36. Biocatal. Biotransform. 33: $141-149$.

Balaban N.P., Suleimanova A.D., Shakirov E. V., Sharipova M.R. 2018. Histidine acid phytases of microbial origin. Microbiol. Russ. Fed. 87: 745-756. 
Baruah K., Norouzitallab P., Pal A.K. 2017. Development of low cost and eco-friendly feed for various candidate species for the sustainability of commercial aquaculture and reduction of aquatic pollution. In: Bagchi D., Nair S. (eds) Developing New Functional Food and Nutraceutical Products. Elsevier, pp. 441-453.

Bhavsar K., Khire J.M. 2014. Current research and future perspectives of phytase bioprocessing. RSC Adv. 4: 2667726691.

Bohn L., Meyer A.S., Rasmussen S.K. 2008. Phytate: Impact on environment and human nutrition. A challenge for molecular breeding. J. Zhejiang Univ. Sci. B 9: 165-191.

Caffaro M.M., Balestrasse K.B., Rubio G. 2019. Adsorption to soils and biochemical characterization of purified phytases. SOIL Discuss. 6: 1-17.

Caipang C.M.A., Dechavez R.B., Amar M.J.A. 2011. Potential application of microbial phytase in aquaculture. ELBA Biofulux 3: 55-66.

Chanderman A., Puri A.K., Permaul K., Singh S. 2016. Production, characteristics and applications of phytase from a rhizosphere isolated Enterobacter sp. ACSS. Bioproc. Biosyst. Eng. 39: 15771587.

Costenaro-Ferreira C., Della Flora M.A.L. 2017. Challenges for efficient use of phytase in fish nutrition. Agrarian 10: 95-104.

Coutinho T.C., Tardioli P.W., Farinas C.S. 2020. Phytase Immobilization on hydroxyapatite nanoparticles improves its properties for use in animal feed. Appl. Biochem. Biotechnol. 190: 270-292.

Dahiya S. 2016. Role of phytate and phytases in human nutrition. Int. J. Food Sci. Nutr. 1: 39-42.

Dersjant-Li Y., Awati A., Schulze H., Partridge G. 2015. Phytase in non-ruminant animal nutrition: A critical review on phytase activities in the gastrointestinal tract and influencing factors. J. Sci. Food Agric. 95: 878-896.

Dev S.S., E.A. N., Venu A. 2016. Biochemical and molecular characterization of efficient phytase producing bacterial isolates from soil samples. Int. J. Curr. Microbiol. Appl. Sci. 5: $218-226$.

Dvořáková J. 1998. Phytase: sources, preparation and exploitation. Folia Microbiol. 43: 323-338.

Elkhalil E.A.I., Männer K., Borriss R., Simon O. 2007. In vitro and in vivo characteristics of bacterial phytases and their efficacy in broiler chickens. British Poultry Sci. 48: 64-70.

Golovan S., Wang G., Zhang J., Forsberg C.W. 1999. Characterization and overproduction of the Escherichia coli appA encoded bifunctional enzyme that exhibits both phytase and acid phosphatase activities. Can. J. Microbiol. 46: 59-71.

Goodfellow M., Fiedler H.P. 2010. A guide to successful bioprospecting: Informed by actinobacterial systematics. Antonie Van Leeuwenhoek 98: 119-142.

Grases F., Costa-Bauza A. 2019. Key aspects of myo-inositol hexaphosphate (phytate) and pathological calcifications. Molecules 24: 4434.

Greiner R., Carlsson N.G. 2006. myo-inositol phosphate isomers generated by the action of a phytate-degrading enzyme from Klebsiella terrigena on phytate. Can. J. Microbiol. 52: 759-768.

Greiner R., Farouk A.E., Carlsson N.G., Konietzny U. 2007. myoinositol phosphate isomers generated by the action of a phytase from a Malaysian waste-water bacterium. Protein J. 26: $577-584$.

Guder D.G., Krishna M.S.R. 2019. Isolation and characterization of potential cellulose degrading bacteria from sheep rumen. J.
Pure Appl. Microbiol. 13: 1831-1839.

Helian Y., Gai Y., Fang H., Sun Y., Zhang D. 2020. A multistrategy approach for improving the expression of E. coli phytase in Pichia pastoris. J. Ind. Microbiol. Biotechnol. 47: 1161-1172.

Ibnu Irwan I., Agustina L., Natsir A., Ahmad A. 2017. Isolation and characterization of phytase-producing thermophilic bacteria from Sulili Hot Springs in South Sulawesi. Sci. Res. J. 5: 16.

Igual J.M., Valverde A., Cervantes E., Velázquez E. 2001. Phosphatesolubilizing bacteria as inoculants for agriculture: Use of updated molecular techniques in their study. Agronomie 21: 561-568.

Jatuwong K., Suwannarach N., Kumla J., Penkhrue W., Kakumyan P., Lumyong S. 2020. Bioprocess for production, characteristics, and biotechnological applications of fungal phytases. Front. Microbiol. 11: 1-18.

Jeske L., Placzek S., Schomburg I., Chang A., Schomburg D. 2019. BRENDA in 2019: A European ELIXIR core data resource. Nucleic Acids Res. 47: 542-549.

Jorquera M.A., Crowley D.E., Marschner P., Greiner R., Fernández M.T., Romero D., Menezes-Blackburn D., De La Luz Mora M. 2011. Identification of $\beta$-propeller phytase-encoding genes in culturable Paenibacillus and Bacillus spp. from the rhizosphere of pasture plants on volcanic soils. FEMS Microbiol. Ecol. 75: 163-172.

Jorquera M.A., Gabler S., Inostroza N.G., Acuña J.J., Campos M.A., Menezes-Blackburn D., Greiner R. 2018. Screening and characterization of phytases from bacteria isolated from Chilean hydrothermal environments. Microb. Ecol. 75: 387399.

Kalsi H.K., Singh R., Dhaliwal H.S., Kumar V. 2016. Phytases from Enterobacter and Serratia species with desirable characteristics for food and feed applications. 3 Biotech. 6: 1-13.

Kandil M.M. 2017. Isolation and characterization of highly effective phytate-mineralizing Klebsiella pneumonia strain MK1C adapted to arid and semiarid conditions from calcareous soil. Alexandria Sci. Exch. J. 38: 819-827.

Karpagam T.,Nagalakshmi P.K.2014.Isolation and characterization of phosphate solubilizing microbes from agricultural soil. Int. J. Curr. Microbiol. Appl. Sci. 3: 601-614.

Kerovuo J., Lauraeus M., Nurminen P., Kalkkinen N., Apajalahti J. 1998. Isolation, characterization, molecular gene cloning, and sequencing of a novel phytase from Bacillus subtilis. Appl. Environ. Microbiol. 64: 2079-2085.

Khan A., Ghosh K. 2012. Characterization and identification of gut-associated phytase-producing bacteria in some fresh water fish cultured in ponds. Acta Ichthyol. Piscat. 42: 37-45.

Khianngam S., Pootupaaeng-on Y., Sonloy A., Kajorn-aroonkij J., Tanasupawat S. 2017. Characterization and comparison of phytase production by Bacillus and Paenibacillus strains from Thai soils. Malays. J. Microbiol. 13: 318-325.

Kim B.H., Lee J.Y., Lee P.C.W. 2015. Purification, sequencing and evaluation of a divergent phytase from Penicillium oxalicum KCTC6440. J. Gen. Appl. Microbiol. 61: 117-123.

Konietzny U., Greiner R. 2004. Bacterial phytase: Potential application, in vivo function and regulation of its synthesis. Braz. J. Microbiol. 35: 11-18.

Kumar D., Rajesh S., Balashanmugam P., Rebecca L.J., Kalaichelvan P.T. 2013. Screening, optimization and application of extracellular phytase from Bacillus megaterium isolated from poultry waste. J. Modern Biotechnol. 2: 46-52.

Kumar V., Singh P., Jorquera M.A., Sangwan P., Kumar P., Verma A.K., Agrawal S. 2013. Isolation of phytase-producing 
bacteria from Himalayan soils and their effect on growth and phosphorus uptake of Indian mustard (Brassica juncea). World J. Microbiol. Biotechnol. 29: 1361-1369.

Kumar V., Sinha A.K., Makkar H.P.S., Becker K. 2010. Dietary roles of phytate and phytase in human nutrition: A review. Food Chem. 120: 945-959.

Kumar V., Yadav A.N., Saxena A., Sangwan P. 2016. Unravelling rhizospheric diversity and potential of phytase producing microbes. SM J. Biol. 2: 1-2.

Kumar V., Yadav A.N., Verma P., Sangwan P., Saxena A., Kumar K., Singh B. 2017. $\beta$-Propeller phytases: Diversity, catalytic attributes, current developments and potential biotechnological applications. Int. J. Biol. Macromol. 98: 595609.

Kushwaha M., Surabhi, Marwa N., Pandey V., Singh N. 2020. Advanced tools to assess microbial diversity and their functions in restoration of degraded ecosystems. In: Singh J.S., Vimal S.R. (eds) Microbial Services in Restoration Ecology. Elsevier, pp. 83-97.

Lee D.-H., Choi S.-U., Hwang Y.-I. 2005. Culture conditions and characterizations of a new phytase-producing fungal isolate, Aspergillus sp. L117. Mycobiology 33: 223-229.

Lei X.G., Porres J.M. 2003. Phytase enzymology, applications, and biotechnology. Biotechnol. Lett. 25: 1787-1794.

Li Y., Xu H., Xu J., Pang R., Xu B. 2019. Structure prediction and enzymatic properties of phytase phyS. Adv. Enzym. Res. 7: $57-65$.

López Ortega M.D.P., Criollo Campos P.J., Gómez Vargas R.M., Camelo Runsinque M., Estrada Bonilla G., Garrido Rubiano M.F., Bonilla Buitrago R. 2013. Characterization of diazotrophic phosphate solubilizing bacteria as growth promoters of maize plants. Rev. Colomb. Biotecnol. 15: 115123.

Miao Y.-Z., Xu H., Fei, Bao-Jin, Qiao, Dai-Rong, Cao Y. 2013. PCR - RFLP analysis of the diversity of phytate-degrading bacteria in the Tibetan Plateau. Can. J. Microbiol. 251: 245-251.

Mittal A., Singh G., Goyal V., Yadav A., Aneja K.R., Gautam S.K., Aggarwal N.K. 2011. Isolation and biochemical characterization of acido-thermophilic extracellular phytase producing bacterial strain for potential application in poultry feed. Jundishapur J. Microbiol. 4: 273-282.

Monika, Savitri, Kumar V., Kumari A., Angmo K., Bhalla T.C. 2017. Isolation and characterization of lactic acid bacteria from traditional pickles of Himachal Pradesh, India. J. Food Sci. Technol. 54: 1945-1952.

Motamedi H. 2016. Screening cabbage rhizosphere as a habitat for isolation of phosphate-solubilizing bacteria. Environ. Exp. Biol. 14: 173-181.

Mullaney E.J., Ullah A.H.J. 2003. The term phytase comprises several different classes of enzymes. Biochem. Biophys. Res. Commun. 312: 179-184.

Muslim S.N., AL-Kadmy I.M.S, Khazaal S.S., Ali A.N.M., Ibrahim S.A., Al-Saryi N.A., Al-saadi L.G., Muslim S.N., Salman B.K., Aziz S.N. 2018. Screening, nutritional optimization and purification for phytase produced by Enterobacter aerogenes and its role in enhancement of hydrocarbons degradation and biofilm inhibition. Microb. Pathog. 115: 159-167.

Nasrabadi R.G., Greiner R., Yamchi A., Nourzadeh Roshan E. 2018. A novel purple acid phytase from an earthworm cast bacterium. J. Sci. Food Agric. 98: 3667-3674.

Okamoto A.K., Miranda M.A., Granjeiro J.M., Aoyama H. 2017. Enzymes with two optimum $\mathrm{pH}$ values. World J. Res. Rev. 5:
$5-11$.

Onawola O.O., Akande I.S., Okunowo W.O., Osuntoki A.A. 2019. Isolation and identification of phytase-producing Bacillus and Enterobacter species from Nigerian soils. Niger. J. Biotechnol. 36: $127-138$.

Onipede G., Aremu B., Sanni A., Babalola O. 2020. Molecular study of the phytase gene in lactic acid bacteria isolated from ogi and kunun-zaki, african fermented cereal gruel and beverage. Appl. Food Biotechnol. 7: 49-60.

Park I., Lee J., Cho J.2012. Degradation of phytate pentamagnesium salt by Bacillus sp. T4 phytase as a potential eco-friendly feed additive. Asian-Australasian J. Anim. Sci. 25: 1466-1472.

Rahman S.S., Siddique R., Tabassum N. 2017. Isolation and identification of halotolerant soil bacteria from coastal Patenga area. BMC Res. Notes 10: 4-9.

Ramesh A., Sharma S.K., Joshi O.P., Khan I.R. 2011. Phytase, phosphatase activity and p-nutrition of soybean as influenced by inoculation of Bacillus. Indian J. Microbiol. 51: 94-99.

Rocky-Salimi K., Hashemi M., Safari M., Mousivand M. 2016. A novel phytase characterized by thermostability and high $\mathrm{pH}$ tolerance from rice phyllosphere isolated Bacillus subtilis B.S.46. J. Adv. Res. 7: 381-390.

Roy T., Mondal S., Ray A.K. 2009. Phytase-producing bacteria in the digestive tracts of some freshwater fish. Aquacult. Res. 40: 344-353.

Sajidan A., Farouk A., Greiner R., Jungblut P., Müller E.C., Borriss R. 2004. Molecular and physiological characterisation of a 3-phytase from soil bacterium Klebsiella sp. ASR1. Appl. Microbiol. Biotechnol. 65: 110-118.

Sajidan, Wulandari R., Sari E.N., Ratriyanto A., Weldekiros H., Greiner R. 2015. Phytase-producing bacteria from extreme regions in Indonesia. Brazilian Arch. Biol. Technol. 58: 711717.

Sanguin H., Wilson N.L., Kertesz M.A. 2016. Assessment of functional diversity and structure of phytate-hydrolysing bacterial community in Lolium perenne rhizosphere. Plant Soil 401: 151-167.

Savita P., Yallappa M., Nivetha N., Suvarna V. 2017. Phytate solubilizing microorganisms and enzyme phytase to combat nutritional problems in cereal-based foods. J. Bacteriol. Mycol. 4: 86-89.

Shobirin A., Hussin M., Farouk A., Salleh H.M. 2010. Phytatedegrading enzyme and its potential biotechnological application: a review. J. Agrobiotechnology 1: 1-16.

Siddque R., Alif F. 2018. Isolation and identification of Orange M2R and Green GS dye decolourizing bacteria from textile sludge (soil) samples and determination of their optimum decolourization conditions. Annu. Res. Rev. Biol. 22: 1-12.

Singh N.K., Joshi D.K., Gupta R.K. 2013. Isolation of phytase producing bacteria and optimization of phytase production parameters. Jundishapur J. Microbiol. 6: e6419.

Singh P., Kumar V., Agrawal S. 2014. Evaluation of phytase producing bacteria for their plant growth promoting activities. Int. J. Microbiol. 2014: 426483.

Van Staden J., Den Haan R., Van Zyl W.H., Botha A., ViljoenBloom M. 2007. Phytase activity in Cryptococcus laurentii ABO 510. FEMS Yeast Res. 7: 442-448.

Stoica C., Sorescu I. 2017. ABIS online - Advanced Bacterial Identification Software, an original tool for phenotypic bacterial identification. Regnum Prokaryotae 10: 1-13.

Suleimanova A.D., Beinhauer A., Valeeva L.R., Chastukhina I.B., Balaban N.P., Shakirov E. V., Greiner R., Sharipova M.R. 2015. 
Novel glucose-1-phosphatase with high phytase activity and unusual metal ion activation from soil bacterium Pantoea sp. strain 3.5.1. Appl. Environ. Microbiol. 81: 6790-6799.

Suliasih S., Widawati S. 2020. Phytase production in Enterobacter cloacae. Biotropia 27: 282-291.

Tran T.T., Hashim S.O., Gaber Y., Mamo G., Mattiasson B., HattiKaul R. 2011. Thermostable alkaline phytase from Bacillus sp. MD2: Effect of divalent metals on activity and stability. J. Inorg. Biochem. 105: 1000-1007.

Tran T.T., Mamo G., Búxo L., Le N.N., Gaber Y., Mattiasson B., Hatti-Kaul R. 2011. Site-directed mutagenesis of an alkaline phytase: Influencing specificity, activity and stability in acidic milieu. Enzyme Microb. Technol. 49: 177-182.

Tye A., Siu F., Leung T., Lim B. 2002. Molecular cloning and the biochemical characterization of two novel phytases from $B$. subtilis 168 and B. licheniformis. Appl. Microbiol. Biotechnol. 59: 190-197.

Ushasree M.V., Shyam K., Vidya J., Pandey A. 2017. Microbial phytase: Impact of advances in genetic engineering in revolutionizing its properties and applications. Bioresour. Technol. 245: 1790-1799.

Wang T., Li W., Hao Y., Liu Y. 2015. Enzymatic properties of phytase from Escherichia coli DH5a. Int. Conf. Chem. Mater. Food Eng. 22: 88-92. 